\title{
Peak Oxygen Consumption Measured during the Stair-Climbing Test in Lung Resection Candidates
}

\author{
Alessandro Brunelli Francesco Xiumé Majed Refai Michele Salati \\ Luca Di Nunzio Cecilia Pompili Armando Sabbatini \\ Division of Thoracic Surgery, Ospedali Riuniti, Ancona, Italy
}

\section{Key Words}

Evaluation, preoperative $\cdot$ Exercise test $\cdot$ Lung resection .

Stair-climbing test $\cdot \mathrm{VO}_{\text {2peak }}$

\begin{abstract}
Background: The stair-climbing test is commonly used in the preoperative evaluation of lung resection candidates, but it is difficult to standardize and provides little physiologic information on the performance. Objective: To verify the association between the altitude and the $\mathrm{Vo}_{2 \text { peak }}$ measured during the stair-climbing test. Methods: 109 consecutive candidates for lung resection performed a symptomlimited stair-climbing test with direct breath-by-breath measurement of $\mathrm{VO}_{2 \text { peak }}$ by a portable gas analyzer. Stepwise logistic regression and bootstrap analyses were used to verify the association of several perioperative variables with a $\mathrm{VO}_{2 \text { peak }}<15 \mathrm{ml} / \mathrm{kg} / \mathrm{min}$. Subsequently, multiple regression analysis was also performed to develop an equation to estimate $\mathrm{VO}_{2 \text { peak }}$ from stair-climbing parameters and other patient-related variables. Results: $56 \%$ of patients climbing $<14 \mathrm{~m}$ had a $\mathrm{VO}_{2 \text { peak }}<15 \mathrm{ml} / \mathrm{kg} / \mathrm{min}$, whereas $98 \%$ of those climbing $>22 \mathrm{~m}$ had a $V_{2} O_{2 \text { peak }}>15 \mathrm{ml} / \mathrm{kg} / \mathrm{min}$. The altitude reached at stair-climbing test resulted in the only significant
\end{abstract}

predictor of a $\mathrm{VO}_{2 \text { peak }}<15 \mathrm{ml} / \mathrm{kg} / \mathrm{min}$ after logistic regression analysis. Multiple regression analysis yielded an equation to estimate $\mathrm{VO}_{2 \text { peak }}$ factoring altitude $(p<0.0001)$, speed of ascent $(p=0.005)$ and body mass index $(p=0.0008)$. Conclusions: There was an association between altitude and $\mathrm{VO}_{2 \text { peak }}$ measured during the stair-climbing test. Most of the patients climbing more than $22 \mathrm{~m}$ are able to generate high values of $\mathrm{VO}_{2 \text { peak }}$ and can proceed to surgery without any additional tests. All others need to be referred for a formal cardiopulmonary exercise test. In addition, we were able to generate an equation to estimate $\mathrm{VO}_{2 \text { peak, }}$, which could assist in streamlining the preoperative workup and could be used across different settings to standardize this test.

Copyright $\odot 2010$ S. Karger AG, Basel

\section{Introduction}

The stair-climbing test is one of the most frequently used low-technology exercise tests in the preoperative evaluation of lung resection candidates [1]. It is appealing because of its simplicity, economy and ability to predict postoperative complications [2-5]. For these reasons, it was proposed as one of the first-line screening tests in the

\section{KARGER}

Fax +41613061234 E-Mail karger@karger.ch www.karger.com
(C) 2010 S. Karger AG, Basel

0025-7931/10/0803-0207\$26.00/0

Accessible online at:

www.karger.com/res
Dr. A. Brunelli

Division of Thoracic Surgery, Ospedali Riuniti

IT-60020 Ancona (Italy)

Tel. +39 071596 4433, Fax +390715964481

E-Mail brunellialex@gmail.com 
recent ERS-ESTS guidelines for evaluating fitness for radical therapy [6].

However, the test has 2 major problems: (1) it is difficult to standardize owing to infrastructural differences between hospitals, and (2) like all low-technology tests, it provides only limited physiologic information regarding the factors affecting performance.

Based on these premises, we analyzed a series of patients undergoing the stair-climbing test as part of their routine institutional preoperative functional workup [7] and measured their exercise oxygen consumption by means of a portable telemetric gas analyzer. The objective was to verify whether there could be an association between the altitude climbed, which is the parameter most commonly used to stratify the peri-operative risk, and the $\mathrm{VO}_{2 \text { peak }}$ measured during the effort. Moreover, we wanted to develop a regression equation which could estimate the $\mathrm{VO}_{2 \text { peak }}$ and help to streamline the preoperative workup of these patients.

\section{Patients and Methods}

One hundred and nine candidates for lung resection for nonsmall cell lung cancer who were evaluated during a 12-month period (2008) were included in the analysis. The protocol was approved by the local institutional review board and all patients gave their informed consent to perform the exercise and participate in the study. All the enrolled patients performed a maximal stairclimbing test as a part of their routine preoperative functional workup according to our institutional protocol [7]. During the same period another 10 patients were not able to perform the test due to concomitant severe incapacitating co-morbidities or contraindication to its performance.

The stair-climbing test was performed as a symptom-limited exercise test. Patients were instructed to climb, at a pace of their own choice, the maximum number of steps and to stop only for exhaustion, limiting dyspnea, leg fatigue or chest pain. All patients were accompanied by a trained physician for symptom assessment and were continuously monitored by means of pulse oximeter. The test was performed in room air and with direct breath-by-breath measurement of expired gases through a portable telemetric gas analyzer (Oxycon Mobile; Viasys Healthcare $\mathrm{GmbH}$, Hoechberg, Germany) that weighed $950 \mathrm{mg}$ and was carried by the subjects through a comfortable belt system attached to the chest. A validation of the parameters measured with this device has been previously published [8]. Blood pressure and respiratory rate were also measured before and immediately after completion of the test. The test was performed on a staircase located centrally in the main building of the hospital and easily accessible in case of severe complications requiring advanced care management. The staircase was composed of 7 flights of stairs. Each flight was 22 steps, each of which was $0.155 \mathrm{~m}$ in height. The altitude climbed (number of steps multiplied by 0.155 ), speed of ascent $(\mathrm{m} / \mathrm{min})$ and $\mathrm{VO}_{2 \text { peak }}$ were recorded for each patient.
Statistical Analysis

Stepwise logistic regression analysis was used to verify the independent association of several factors (including stair altitude and speed of ascent) with a $\mathrm{VO}_{2 \text { peak }}<15 \mathrm{ml} / \mathrm{kg} / \mathrm{min}$ (binary dependent variable). The following variables were used in the analysis: age, gender, body mass index, forced expiratory volume in $1 \mathrm{~s}\left(\mathrm{FEV}_{1}\right)$, carbon monoxide lung diffusion capacity, $\mathrm{FEV}_{1} /$ FVC ratio, preoperative haemoglobin level, smoking pack-years, presence of coronary artery disease, presence of peripheral vascular disease, height climbed at stair-climbing test and speed of ascent. Initially, variables were screened for a possible association with a $\mathrm{VO}_{2 \text { peak }}<15 \mathrm{ml} / \mathrm{kg} / \mathrm{min}$ by univariate analysis. Normal distribution was tested by the Shapiro Wilk test. Continuous variables with normal distribution were compared by the unpaired Student's t test, those without normal distribution with the Mann-Whitney test. Categoric variables were compared by the $\chi^{2}$ test or Fisher's exact test as appropriate. Only significant variables $(\mathrm{p}<0.05)$ were used as independent variables in the stepwise logistic regression. Furthermore, to avoid multicollinearity, only 1 variable in a set of variables with a correlation coefficient $>0.5$ was selected (by bootstrap) and used in the regression analysis.

Subsequently, all variables were entered into a stepwise multiple regression analysis was performed to yield an equation estimating $\mathrm{VO}_{2 \text { peak }}$ (expressed as a continuous variable) from stairclimbing parameters and other patients-related variables. Bootstrap resampling analysis was used to assess reliability of the significant variables in the regression analyses. Regression was repeated in 1,000 bootstrap samples of the same size as the original population and drawn with replacement from the original dataset. Reliability of the predictors was assessed by the frequency of their significancy in 1,000 bootstrap samples [9-11]. If predictors are significant in more than $50 \%$ of samples they are deemed reliable. All variables in this set of patients were complete. To avoid multicollinearity, only 1 variable in a set of variables with a correlation coefficient greater than 0.5 was used in the regression after selection with bootstrap analysis. $\mathrm{p}<0.05$ was regarded as significant. The analysis was performed on Stata 9.0 statistical software (Stata, College Station, Tex., USA).

\section{Results}

The characteristics of the patients in the study are displayed in table 1 .

Table 2 and figure 1 show the breakdown of the altitude reached at stair climbing test and the $\mathrm{VO}_{2 \text { peak }}$ measured at the peak of the test. There is a high correlation between altitude and $\mathrm{VO}_{2 \text { peak }}$ as indicated by the fact that $56 \%$ of patients not reaching $14 \mathrm{~m}$ had a $\mathrm{VO}_{2}$ below 15 $\mathrm{ml} / \mathrm{kg} / \mathrm{min}$. On the other hand, those climbing more than $22 \mathrm{~m}$ had a $\mathrm{VO}_{2}$ level greater than $15 \mathrm{ml} / \mathrm{kg} / \mathrm{min}$ and greater than $20 \mathrm{ml} / \mathrm{kg} / \mathrm{min}$ in $98 \%$ and $63 \%$ of cases, respectively.

Furthermore, the correlation coefficient between $\mathrm{VO}_{2 \text { peak }}$ and altitude was as high as $0.7(\mathrm{p}<0.0001)$. Fig- 


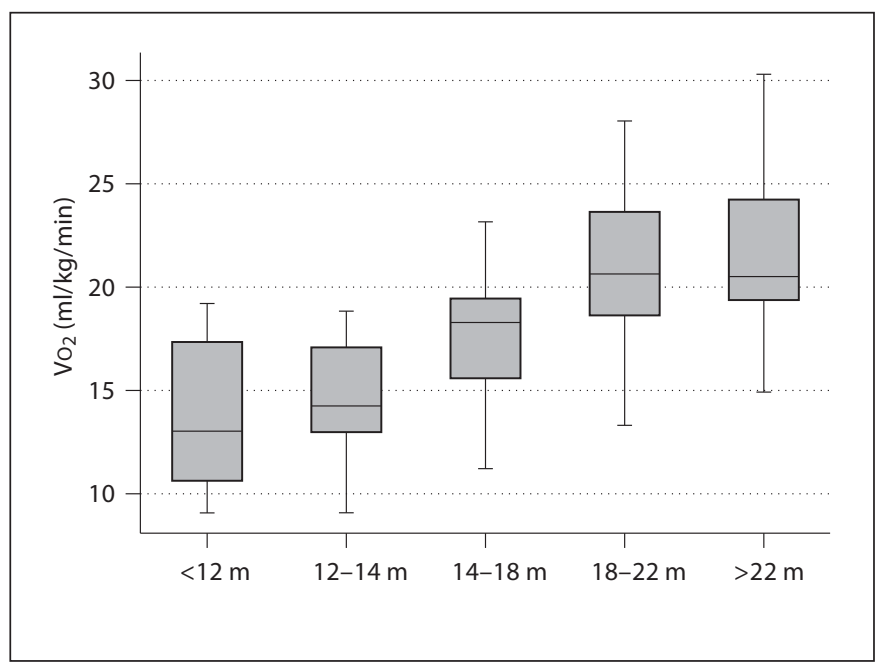

Fig. 1. Box plot distribution of $\mathrm{VO}_{2 \text { peak }}$ measured during the stairclimbing test in patients grouped by stair-climbing altitude. The boxes display the median, 25 th and 75 th percentiles. Whiskers extend to the upper and lower adjacent values (the values most adjacent to points represented by the 25 th or 75 th percentile plus 1.5 times the interquartile range). Outliers are excluded.

Table 1. Characteristics of patients under analysis $(\mathrm{n}=109)$

\begin{tabular}{lc}
\hline Variables & \\
\hline Age, year & $66.6 \pm 11.1$ \\
Males, $\mathrm{n}$ & $83(78 \%)$ \\
$\mathrm{BMI}$ & $26.6 \pm 4.4$ \\
$\mathrm{FEV}, \%$ & $84 \pm 19$ \\
$\mathrm{DLCO}, \%$ & $79.8 \pm 18.9$ \\
$\mathrm{CAD}$ & $19(17 \%)$ \\
$\mathrm{PVD}$ & $18(16 \%)$ \\
Altitude climbed, $\mathrm{m}$ & $19 \pm 4.7$ \\
Speed, $\mathrm{m} / \mathrm{min}$ & $10 \pm 2.4$ \\
VO $_{2 \text { peak }}(\mathrm{ml} / \mathrm{kg} / \mathrm{min})$ & $19 \pm 4.7$ \\
VO $_{2 \text { peak\% }}$ & $73.3 \pm 15.3 \%$ \\
\hline
\end{tabular}

Results are expressed as means \pm SD unless otherwise specified. $\mathrm{VO}_{2 \text { peak }}(\mathrm{ml} / \mathrm{kg} / \mathrm{min})$ and $\mathrm{VO}_{2 \text { peak\% }}$ are measured during the stair-climbing test. $\mathrm{BMI}=$ Body mass index $; \mathrm{CAD}=$ coronary artery disease; DLCO = carbon monoxide lung diffusion capacity; $\mathrm{PVD}=$ Peripheral Vascular Disease.

ure 2 shows the linear relationship between altitude climbed and $\mathrm{VO}_{2 \text { peak }}$ measured during stair climbing.

The altitude reached in the stair-climbing test was the

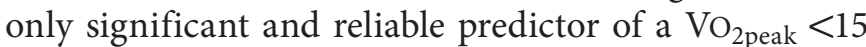
$\mathrm{ml} / \mathrm{kg} / \mathrm{min}$ after logistic regression analysis and boot-

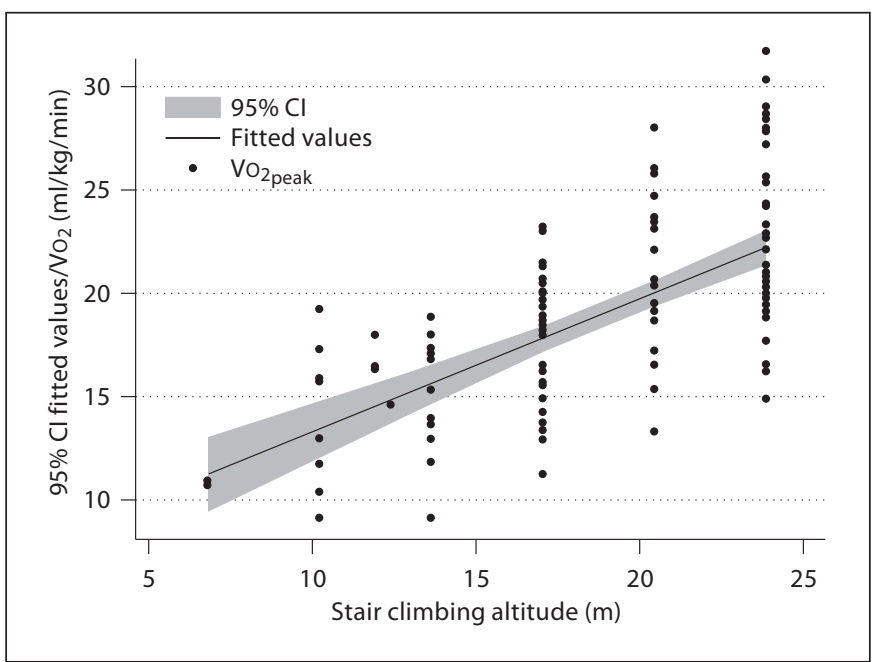

Fig. 2. Scatter plot distribution of $\mathrm{VO}_{2 \text { peak }}$ measured during the stair-climbing test, indicating a linear positive correlation with climbed altitude. The black line and shaded area represent bestfitted values and their 95\% CI, respectively. Results of linear regression: $\mathrm{VO}_{2}=6.81+0.64 \times$ altitude $($ in $\mathrm{m}$ ), $\mathrm{p}<0.0001$.

Table 2. Stratification of altitude climbed and $\mathrm{VO}_{2 \text { peak }}$ measured during the stair-climbing test

\begin{tabular}{llcl}
\hline Altitude & $\begin{array}{l}\text { Patients } \\
\mathrm{n}\end{array}$ & $\mathrm{VO}_{2 \text { peak }} \mathrm{ml} / \mathrm{kg} / \mathrm{min}$ & $\begin{array}{l}\text { patients, } \mathrm{n} \\
\mathrm{VO}_{2}<15\end{array}$ \\
\hline$<12 \mathrm{~m}$ & 11 & $13(9.9-18.5)$ & $6(55 \%)$ \\
$12-14 \mathrm{~m}$ & 14 & $14.3(11.5-18.1)$ & $8(57 \%)$ \\
$14-18 \mathrm{~m}$ & 25 & $18.3(13.4-20.6)$ & $6(24 \%)$ \\
$18-22 \mathrm{~m}$ & 19 & $20.6(15.8-25.9)$ & $1(5 \%)$ \\
$>22 \mathrm{~m}$ & 40 & $20.5(17.1-28.6)$ & $1(2.5 \%)$ \\
\hline
\end{tabular}
its)

$\mathrm{VO}_{2 \text { peak }}$ values are expressed as medians (90\% confidence lim-

strap $(\mathrm{p}<0.0001$, bootstrap frequency $=100 \%)$. The following regression equation was derived that could predict the risk of having a $\mathrm{VO}_{2 \text { peak }}<15 \mathrm{ml} / \mathrm{kg} / \mathrm{min}$ :

$$
\ln \mathrm{R} /(1+\mathrm{R})=4.08-0.317 \times \text { altitude }(\text { in } \mathrm{m})
$$

The c-index is 0.71 . Positive predictive value for climbing more than $22 \mathrm{~m}$ (predicting a $\mathrm{VO}_{2 \text { peak }}>15 \mathrm{ml} / \mathrm{kg} / \mathrm{min}$ ) was $86 \%$ (although the negative predictive value was only $62 \%)$. The odds $(95 \% \mathrm{CI})$ of having a $\mathrm{VO}_{2}>15 \mathrm{ml} / \mathrm{kg} / \mathrm{min}$ when a patient can climb more than $22 \mathrm{~m}$ were 10 (519). 
Table 3. Results of stepwise multiple regression analysis: parsimonious model

\begin{tabular}{lcccc}
\hline Predictors & Coefficient & SE & p value & $\begin{array}{r}\text { Bootstrap } \\
\text { frequency }\end{array}$ \\
\hline Intercept & 11.17 & & & \\
Altitude & 0.547 & 0.07 & $<0.0001$ & $100 \%$ \\
Speed of ascent & 0.413 & 0.14 & 0.005 & $82 \%$ \\
BMI & -0.248 & 0.07 & 0.0008 & $93 \%$ \\
\hline
\end{tabular}

$\mathrm{BMI}=$ Body mass index. Bootstrap frequency is the frequency of significance $(p<0.05)$ of variable in 1,000 bootstrap samples.

Furthermore, multiple regression analysis yielded an equation to estimate the $\mathrm{VO}_{2 \text { peak }}$ based on altitude, speed of ascent and other preoperative patient-related variables. Table 3 shows the results of multiple regression analysis. Altitude $(\mathrm{p}<0.0001)$, speed of ascent $(\mathrm{p}=0.005)$ and body mass index $(\mathrm{p}=0.0008)$ were independently and reliably associated with $\mathrm{VO}_{2 \text { peak }}$ measured during stair climbing.

The correlation coefficients between $\mathrm{VO}_{2 \text { peak }}$ and each of these predictors were as follows: altitude 0.7 , speed of ascent 0.47 , and BMI -0.3 .

\section{Discussion}

Performance at the stair-climbing test, expressed as height climbed, has been shown to be associated with postoperative outcome $[3-5,12]$. The present analysis showed a direct correlation between the altitude climbed and the oxygen consumption measured during the stairclimbing test, providing a physiologic explanation for this clinical observation. Previous studies have shown that patients able to climb more than $22 \mathrm{~m}$ have a minimal perioperative risk [5]. Based on the present results, this appears justified by the fact that $98 \%$ of these patients were able to generate an oxygen consumption $>15 \mathrm{ml} / \mathrm{kg} /$ min. Conversely, as high as $55 \%$ of those patients deemed at high surgical risk, as they were not able to climb $12 \mathrm{~m}$, were not able to generate an oxygen consumption $>15$ $\mathrm{ml} / \mathrm{kg} / \mathrm{min}$.

These results corroborate recent recommendations from ERS-ESTS guidelines [6] stating that patients must be referred to formal CPET in case of a poor performance $(<22 \mathrm{~m})$ at the stair-climbing test whenever this test is used as a first-line functional screening test.
Based on the present results and considering that, as a

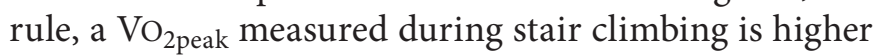
than that measured during cycling [13-15], we think that all patients not reaching $18 \mathrm{~m}$ should be submitted to a formal CPET with analysis of expired gases for a more accurate preoperative risk-stratification.

A recent paper [16] has shown that the speed of ascent is more strictly associated than altitude to $\mathrm{VO}_{2 \text { peak }}$. In this set of patients, speed of ascent had a lower correlation coefficient with $\mathrm{VO}_{2 \text { peak }}$ compared to altitude $(0.47$ vs. 0.7$)$. Moreover, the altitude was the only predictor of $\mathrm{VO}_{2 \text { peak }}<15 \mathrm{ml} / \mathrm{kg} / \mathrm{min}$ (when this variable was used as a binary dependent variable in a logistic regression analysis). Differences in the general fitness of the population under analysis, structure of the stair-climbing test and reference value of $\mathrm{VO}_{2}$ (measured at stair climbing and not during cycle ergometry) may in part explain this discrepancy.

Nevertheless, both speed of ascent and altitude were independently associated with $\mathrm{VO}_{2 \text { peak }}$ after multiple regression analysis. This analysis yielded a model to estimate the $\mathrm{VO}_{2 \text { peak }}$ based on the stair-climbing performance which may assist in the selection of patients to be referred for a more sophisticated exercise test. For instance a patient climbing $12 \mathrm{~m}$ at a speed of $5 \mathrm{~m} / \mathrm{min}$ and with a BMI of 30 would have an estimated $\mathrm{VO}_{2 \text { peak }}$ of only $12.4 \mathrm{ml} / \mathrm{kg} / \mathrm{min}$, whereas one climbing $22 \mathrm{~m}$ at a speed of $10 \mathrm{~m} / \mathrm{min}$ and with a BMI of 22 would have $\mathrm{aO}_{2 \text { peak }}$ of $22 \mathrm{ml} / \mathrm{kg} / \mathrm{min}$.

\section{Potential Study Limitations}

First, the cutoff value of $15 \mathrm{ml} / \mathrm{kg} / \mathrm{min}$ has been selected based on previous studies using a cyclergometry and indicating an increased surgical risk below this threshold [17]. Some authors have demonstrated that the $\mathrm{VO}_{2 \text { peak }}$ generated during stair climbing may be $2-3 \mathrm{ml} /$ $\mathrm{kg} / \mathrm{min}$ higher than the one developed during cycling [15]. Although this needs to be confirmed by more recent investigations in the setting of surgical patients, we can reasonably assume that a patient not reaching $15 \mathrm{ml} / \mathrm{kg} /$ min during stair climbing will be unlikely to do so during cycling.

Second, the stair-climbing test may be difficult to standardize owing to infrastructural differences between hospitals. Differences in the number and height of steps may affect the relationship between altitude and $\mathrm{VO}_{2 \text { peak }}$ and this should be taken into consideration when interpreting the results of this investigation.

Finally, we did not specifically analyse the association between the stair $\mathrm{VO}_{2}$ and postoperative complications in 
the operated patients. In our view, this would have required a different study design and statistical approach, and for this reason will be the subject of a future investigation.

\section{Conclusion}

The present analysis provided a physiologic explanation to the clinical evidence showing the excellent discriminatory capability of the stair-climbing test in stratifying the perioperative risk. We found that more than $50 \%$ of patients not reaching $14 \mathrm{~m}$ may have $\mathrm{VO}_{2 \text { peak }}<15$ $\mathrm{ml} / \mathrm{kg} / \mathrm{min}$, a value warranting more accurate and sophisticated preoperative evaluation (CPET) to optimize the perioperative management. On the other hand, we have confirmed the safety cutoff of $22 \mathrm{~m}$ proposed by the recent ERS-ESTS guidelines [6]. Most of the patients climbing more than $22 \mathrm{~m}$ were able to develop a $\mathrm{VO}_{2 \text { peak }}$ $>20 \mathrm{ml} / \mathrm{kg} / \mathrm{min}$. In addition, we were able to generate an equation to estimate $\mathrm{VO}_{2 \text { peak }}$ based on $\mathrm{BMI}$, stair-climbing altitude and speed. This estimated 'low-tech' $\mathrm{VO}_{2 \text { peak }}$ could further assist in streamlining the preoperative workup of these patients and could be used across different settings as a more comprehensive measure of standardization of this test.

\section{References}

1 Charloux A, Brunelli A, Bolliger CT, Rocco G, Sculier JP, Varela G, Licker M, Ferguson MK, Faivre-Finn C, Huber RM, Clini EM, Win T, De Ruysscher D, Goldman L: Lung function evaluation before surgery in lung cancer patients: how are recent advances put into practice? A survey among members of the European Society of Thoracic Surgeons and of the Thoracic Oncology Section of the European Respiratory Society. Interact Cardiovasc Thorac Surg 2009;9:925-931. DOI: 10.1510/icvts.2009.211219.

- 2 Olsen GN, Bolton JWR, Weiman DS, Hornung CA: Stair climbing as an exercise test to predict the postoperative complications of lung resection. Chest 1991;99:587-590.

-3 Girish M, Trayner E, Damman O, Pinto-Plata V, Celli B: Symptom-limited stair climbing as a predictor of postoperative cardiopulmonary complications after high-risk surgery. Chest. 2001;120:1147-1151.

-4 Brunelli A, Refai M, Monteverde M, Borri A, Salati M, Fianchini A: Stair climbing test predicts cardiopulmonary complications after lung resection. Chest 2002;121:11061110

5 Brunelli A, Refai M, Xiume F, Salati M, Sciarra V, Socci L, Sabbatini A: Performance at symptom-limited stair-climbing test is associated with increased cardiopulmonary complications, mortality, and costs after major lung resection. Ann Thorac Surg 2008;86: 240-247.
-6 Brunelli A, Charloux A, Bolliger CT, Rocco G, Sculier JP, Varela G, Licker M, Ferguson MK, Faivre-Finn C, Huber RM, Clini EM, Win T, De Ruysscher D, Goldman L, European Respiratory Society and European Society of Thoracic Surgeons joint task force on fitness for radical therapy: ERS/ESTS clinical guidelines on fitness for radical therapy in lung cancer patients (surgery and chemoradiotherapy). Eur Respir J 2009;34:17-41.

-7 Brunelli A, Salati M: Preoperative evaluation of lung cancer: predicting the impact of surgery on physiology and quality of life. Curr Opinion Pulm Med 2008;14:275-281.

-8 Perret C, Mueller G: Validation of a new portable ergospirometric device (Oxycon Mobile) during exercise. Int J Sports Med 2006; 2:363-367.

-9 Blackstone EH: Breaking down barriers: helpful breakthrough statistical methods you need to understand better. J Thorac Cardiovasc Surg 2001;122:430-439.

10 Grunkemeier GL, Wu YX: Bootstrap resampling method: something for nothing? Ann Thorac Surg 2004;77:1142-1144.
11 Brunelli A, Rocco G: Internal validation of risk models in lung resection surgery: bootstrap versus training-and-test sampling. J Thorac Cardiovasc Surg Jun 2006;131:12431247.

12 Pate P, Tenholder MF, Griffin JP, Eastridge CE, Weiman DS: Preoperative assessment of the high-risk patient for lung resection. Ann Thorac Surg 1996;61:1494-1500.

$\checkmark 13$ Holden DA, Rice TW, Stelmach K, Meeker DP: Exercise testing, 6-min walk, and stair climb in the evaluation of patients at high risk for pulmonary resection. Chest 1992; 102:1774-1779.

14 Pollock M, Roa J, Benditt J, Celli B: Estimation of ventilatory reserve by stair climbing: a study in patients with chronic airflow obstruction. Chest 1993;104:1378-1383.

15 Swinburn CR, Wakefield JM, Jones PW: Performance, ventilation and oxygen consumption in three different types of exercise test in patients with chronic obstructive lung disease. Thorax 1985;40:581-586.

16 Koegelenberg CF, Diacon AH, Irani S, Bolliger CT: Stair climbing in the functional assessment of lung resection candidates. Respiration 2008;75:374-379.

$>17$ BTS guidelines: guidelines on the selection of patients with lung cancer for surgery. Tho$\operatorname{rax} 2001 ; 56: 89-108$. 